\title{
Electronically tunable current-mode multifunction filter using current-controlled current follower transconductance amplifier
}

\author{
Montree Kumngern ${ }^{1}$, Fabian Khateb $^{2,3}$, Pipat Prommee ${ }^{1}$, Winai Jaikla ${ }^{4}$
}

${ }^{1}$ King Mongkut's Institute of Technology Ladkrabang, Faculty of Engineering, Department of Telecommunications Engineering, Bangkok, Thailand

${ }^{2}$ Brno University of Technology, Department of Microelectronics, Brno, Czech Republic.

${ }^{3}$ Czech Technical University in Prague, Faculty of Biomedical Engineering, Kladno, Czech Republic ${ }^{4}$ King Mongkut's Institute of Technology Ladkrabang, Faculty of Industrial Education and technology, Department of Engineering Education, Bangkok, Thailand

\begin{abstract}
A new electronically tunable current-mode multifunction universal filter with three inputs and one output based on current-controlled current follower transconductance amplifier is presented. The proposed filter can implement low-pass, band-pass, high-pass, band-stop and all-pass transfer functions with a single topology. For implementation of these transfer functions, no passive component-matching conditions, no inverted input signal requirements and high-output impedance are required. Also the proposed filter offers electronic control of the natural angular frequency, low active and passive sensitivities and use of grounded capacitors which is ideal for integrated circuit implementation. The proposed universal biquadratic filter has been used for implementing sixthorder filters. PSPICE simulation results confirm the presented theory.
\end{abstract}

Keywords: Universal filter; current follower transconductance amplifier (CFTA); current-controlled CFTA (CCFTA); current-mode circuit; high-order filter

\section{Elektronsko nastavljiv multifunkcïski filter v tokovnem načinu za uporabo $v$ tokovno krmiljenem transkonduktančnem ojačevalniku}

\begin{abstract}
Izvleček: Predstavljen je nov elektronsko nastavljiv multifunkcijski filter v tokovnem načinu s tremi vhodi in enim izhodom na osnovi tokovno krmiljenega transkonduktančnega ojačevalnika. Predlagan filter lahko vsebuje, nizko pasovno, pasovno, visoko pasovno, pasovno blokirno in vse-propustno prenosno funkcijo v enojni topologiji. Za implementacijo propustnih funkcij ne potrebujemo pogoje usklajenosti pasivnih komponent, invertiranih vhodnih signalov ali visokih izhodnih impedanc. Filter prav tako omogoča elektronski nadzor naravne kotne frekvence, nizko aktivno in pasivno občutljivost in ozemljene kondenzatorje, ki so idealni za implementacijo v integrirana vezja. Predlagan filter je bil uporabljen kot filter šestega red in simuliran v okolju PSPICE.
\end{abstract}

Ključne besede: univerzalni filter; tokovni transkonduktančni ojačevalnik; tokovno krmiljenje; filter visokega reda

*Corresponding Author's e-mail: kkmontre@gmail.com

\section{Introduction}

The universal biquadratic filters are classified as second-order filters that typically implement five filtering functions with a single topology such as low-pass (LP), band-pass (BP), high-pass (HP), band-stop (BS) and all-pass (AP) transfer functions. The biquadratic filters can be used in electronic and communication systems such as phase locked loop (PLL), touch-tone telephone tone decoder, cross-over network for a three-way high-fidelity loudspeaker [1]. It is also well-known that 
biquadratic filter can be used for implementing highorder filters [2]. As a result, many universal biquadratic filters are reported; see, for example [3]-[26]. Considering the input and output terminals, these filters can be classified in three categories, that are a single-input multiple-output (SIMO) filter, a multiple-output singleinput (MISO) filter and a multiple-input multiple-output (MIMO) filter. When a single signal is applied at the input of a SIMO filter, filtering functions such as LP, BP, $\mathrm{HP}, \mathrm{BS}$ and AP functions can be obtained at each output terminal. Thus, a SIMO filter can generate the response to several filtering functions without changing the input terminal and without requiring additional circuitry. Unfortunately, a SIMO filter normally requires several active and passive devices, if five standard filtering functions are implemented. Compared with SIMO filter, MISO and MIMO filters require fewer active and passive components, because the filtering function is selected by appropriately applying the input signals and/or selecting the output signals. However, if five filtering functions are required, additional summing and subtraction amplifiers are needed. This requirement is difficult especially for voltage-mode (VM) filters where addition and subtraction voltage amplifiers are required using several passive components. Fortunately, this problem is not present in current-mode (CM) filters, because summing and subtracting currents can be implemented in a straightforward manner. Moreover, multiple copies of an input signal can be easily implemented with multiple-output current mirrors.

Current-mode (CM) signal processing circuits received considerable attention because this technique offers several advantages compared to voltage-mode (VM) signal processing circuits, such as greater signal bandwidth, wider dynamic range and especially simpler circuitry [27], [28]. Considering the universal filters in [3-26], the circuits in [3-12] are VM filters while the circuits in [13-26] are CM filters. This paper is focused on the CM filters which are supposed to use only a single active device and grounded capacitors. Several active devices have been used to realize CM universal filters; see, for example [13-33]. The CM filters in [13-17] use second-generation current conveyor (CCIIs) as the active element. However, these structures suffer from a lack of electronic tuning capability. The CM filters with an electronic tuning capability can be realized using operational transconductance amplifiers (OTAs) [1820] and second-generation current-controlled current conveyors (CCCIIs) [21-26], but these circuits use a large number of active elements.

Recently, a new current-mode active device with two current inputs and two kinds of current output referred to as a current differencing transconductance amplifier (CDTA), has been proposed [29]. This device is a synthesis of the well-known advantages of the current differencing buffered amplifier (CDBA) [30] and the transconductance amplifier (TA) to facilitate the implementation of current-mode analog signal processing circuits. Some current-mode universal filters using CDTAs as active elements have been reported in technical literature, see, for example [31-34]. However, these reported filters require more than one CDTA. Moreover, some configurations do not exploit the full capability of the CDTA when typically one of two input terminals of the CDTA is floated and not used [31-33]. Unfortunately, this can cause noise injection in a monolithic circuit [35].

More recently, a new active element with one current input and two kinds of current outputs, the so-called "current follower transconductance amplifier (CFTA)", has been introduced [36]. It is obtained by modifying the original CDTA. It is similar to the CDTA except for current input. The current input of CFTA is operated as a current follower. CFTA-based universal filters were already proposed [37-48]. However, the reported circuits in [37-46] require an excessive number of active components while reported circuits in [47], [48] provide only three filtering functions and some output current terminals do not exhibit high output impedance, thus additional current followers are needed for avoiding the loading problem. Active filters employing only a few active components have a lower power consumption and smaller chip area when implemented as an IC. Also the use of grounded capacitors is suitable for IC implementation [49].

Several current-mode universal filters using a single active element have been proposed in the technical literature; see, for example [50-55]. However, the reported filters suffer from one or more of the following disadvantages: (i) lack of electronic tuning capability [50-52], (ii) use of either floating capacitors or floating resistors [50-53], (iii) cannot provide five standard filtering functions [50], [53], [54], (iv) do not exploit the full capability of the active device when the $y$-terminal of the current conveyor is not used [55].

In this paper, a new electronically tunable currentmode universal filter employing only a modified CFTA and two grounded capacitors, is presented. The proposed circuit can implement LP, BP, HP, BS, and AP filtering functions simultaneously, by appropriately applying the input signals. For realizing these filtering functions, no passive component-matching conditions and no inverted input signal are required. Also the natural angular frequency $\left(\omega_{0}\right)$ can be electronically controlled. The proposed universal filter has been used to realize high-order filters as application examples. PSPICE simulation results confirm the characteristics 
(a)

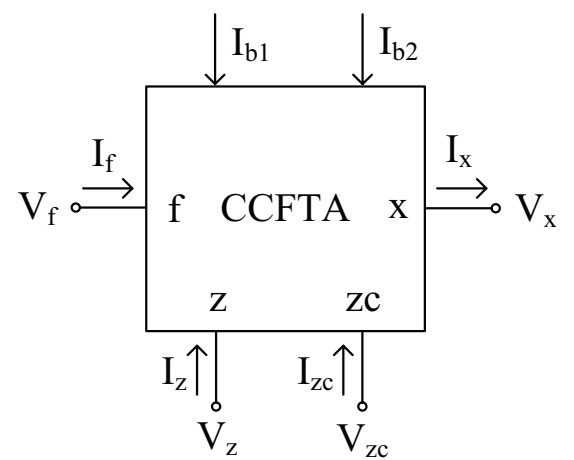

(b)

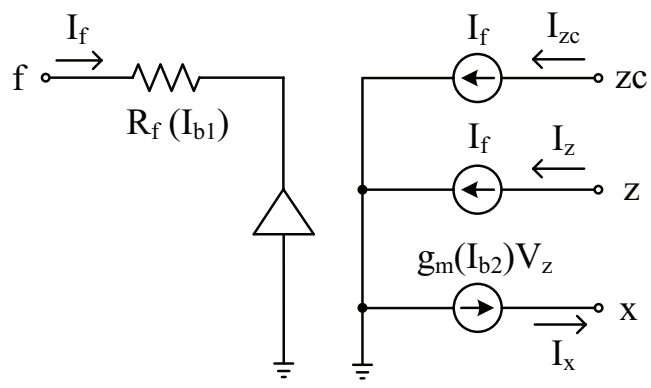

Figure 1: CCFTA: (a) circuit symbol, (b) equivalent circuit.

of the proposed circuit. The comparison between the proposed filter and some previous work is summarized in Table 1. From Table 1 it can be seen that when compared with CCII-based filters in [13-17], the proposed filter provides an electronic tuning capability whereas when compared with filter structures that enjoy an electronic tuning capability in [19-33], the proposed filter uses fewer active elements and when compared with CFTA-based filters in [37-46], the proposed filter uses fewer active and passive elements. Also when compared with the filters using a single active element in [47-55], the proposed filter provides five standard filtering functions, electronic tuning capability, the use of grounded capacitors and high-output impedance.

\section{Circuit realization}

The circuit symbol and the equivalent circuit of the CCFTA are shown in Fig. 1 (a) and (b). The ideal characteristic of CCFTA can be described as

$$
\left(\begin{array}{l}
I_{z} \\
I_{z c} \\
I_{x} \\
V_{f}
\end{array}\right)=\left(\begin{array}{cccc}
0 & 0 & 0 & 1 \\
0 & 0 & 0 & 1 \\
g_{m} & 0 & 0 & 0 \\
0 & 0 & 0 & R_{f}
\end{array}\right)\left(\begin{array}{c}
V_{z} \\
V_{z c} \\
V_{x} \\
I_{f}
\end{array}\right)
$$

where $R_{f}$ and $g_{m}$ are the internal resistance at the $f-$ terminal and the transconductance gain of the CCFTA, respectively. The properties of this device are similar to those of the CFTA [36], [42] except for the f-terminal of CCFTA has finite input resistance $R_{f}$ From Fig. $1(b)$, the parasitic resistance $R_{f}$ can be controlled by adjusting the bias current $\mathrm{I}_{\mathrm{b} 1}$. This property makes it different from conventional CFTA. From Fig. 1(a), the transconductance $g_{m}$ can also be controlled by adjusting the bias current $\mathrm{I}_{\mathrm{b} 2}$. The current $\mathrm{I}_{z}$ can be copied to current $\mathrm{I}_{z c}$ at the zc-terminal. This terminal may be called the $z-$ copy terminal [36] and it can be realized both as plusand minus-type zc terminal. Similarly, the plus- and minus-type $x$-terminals can also be obtained.

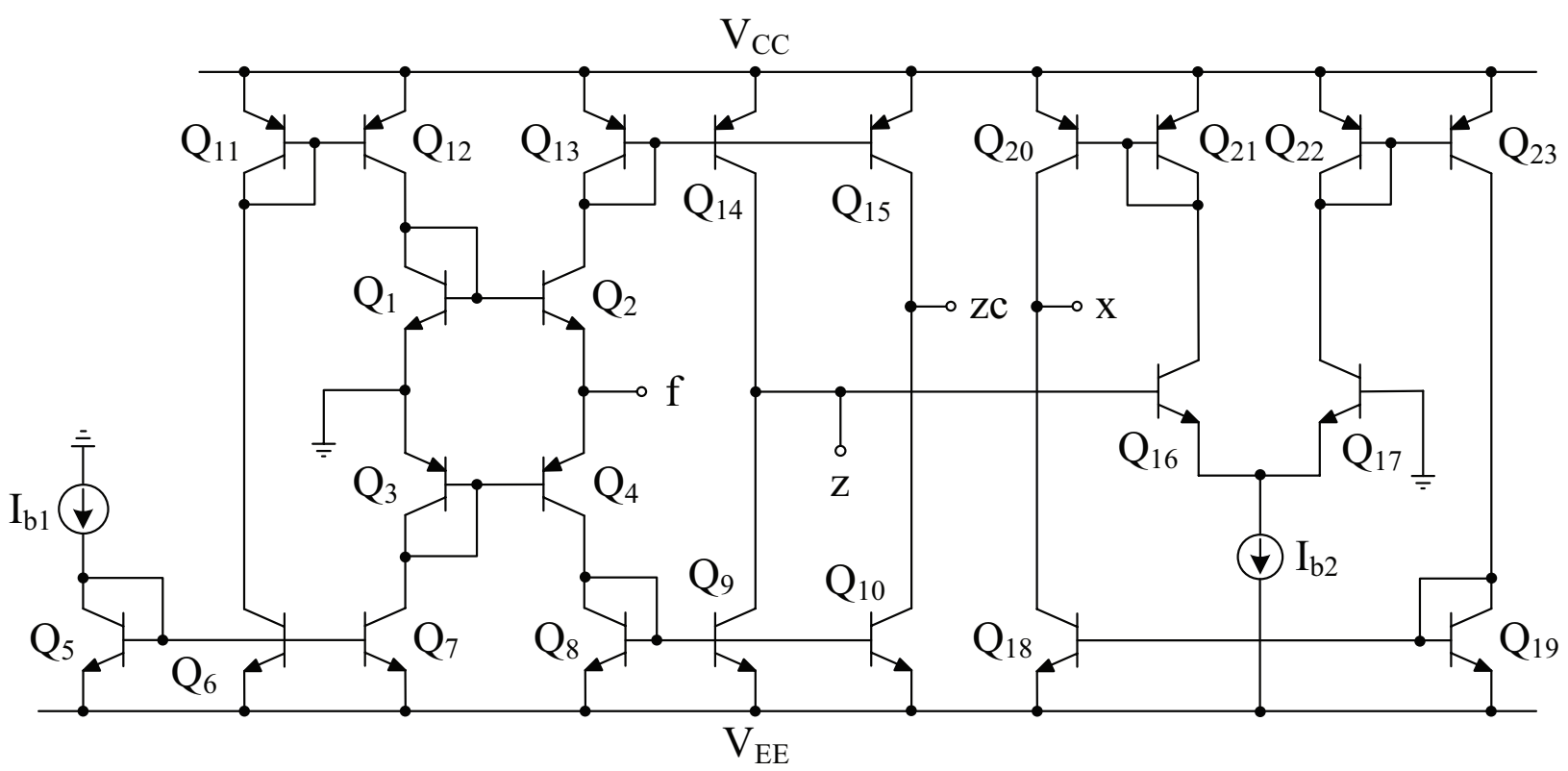

Figure 2: Bipolar implementation of the CCFTA. 
Table 1: Comparison of the proposed filter with existing CM filters (Continued).

\begin{tabular}{|c|c|c|c|c|c|c|c|c|}
\hline Circuits & $\begin{array}{l}\text { Technology or } \\
\text { active device used }\end{array}$ & $\begin{array}{l}\text { Number of } \\
\text { active elements }\end{array}$ & $\begin{array}{l}\text { Number of } \\
\text { resistors }(\mathrm{R}) \& \\
\text { capacitors }(\mathrm{C})\end{array}$ & $\begin{array}{l}\text { Offers five } \\
\text { standard } \\
\text { filters } \\
\text { simulta- } \\
\text { neously }\end{array}$ & $\begin{array}{l}\text { Controlling } \\
\omega_{0} \text { without } \\
\text { affecting Q }\end{array}$ & $\begin{array}{l}\text { All-grounded } \\
\text { passive } \\
\text { components }\end{array}$ & $\begin{array}{l}\text { High-output } \\
\text { impedance }\end{array}$ & $\begin{array}{l}\text { Operational } \\
\text { frequency } \\
\text { (simulated) }\end{array}$ \\
\hline $\begin{array}{l}\text { Proposed } \\
\text { filters }\end{array}$ & HFA3096 (BJT) & 1-CCFTA & $2-C$ & Yes & Yes & Yes & Yes & $>100 \mathrm{MHz}$ \\
\hline \begin{tabular}{|l|} 
Ref. [13] \\
\end{tabular} & AD844N (BJT) & 6-CCII & 6-R \& 2-C & Yes & Yes & Yes & Yes & $>1 \mathrm{MHz}$ \\
\hline \begin{tabular}{|l|} 
Ref. [14] \\
(Fig.8) \\
\end{tabular} & $\begin{array}{l}\text { LM13600, } \\
\text { LF356 (BJT) }\end{array}$ & $10-\mathrm{CCI}$ & 8-R \& 2-C & Yes & Yes & Yes & Yes & $>10 \mathrm{MHz}$ \\
\hline \begin{tabular}{|l|} 
Ref. [15] \\
(Fig.2)
\end{tabular} & AD844N (BJT) & 4-CCII & $2-R \& 2-C$ & Yes & Yes & No & Yes & $>1 \mathrm{MHz}$ \\
\hline \begin{tabular}{|l|} 
Ref. [16] \\
(Fig.3) \\
\end{tabular} & Ad844N (BJT) & $1-\mathrm{CCll}$ & $2-R \& 2-C$ & No & Yes & No & No & $>1 \mathrm{MHz}$ \\
\hline \begin{tabular}{|l|} 
Ref. [17] \\
(Fig.3a) \\
\end{tabular} & $0.35 \mu \mathrm{m}$ CMOS & 1-FDCCII & $2-R \& 2-C$ & Yes & Yes & Yes & Yes & $>100 \mathrm{MHz}$ \\
\hline Ref. [18] & $0.5 \mu \mathrm{m}$ CMOS & 4-OTA & $2-C$ & Yes & Yes & No & Yes & $>10 \mathrm{MHz}$ \\
\hline Ref. [19] & $0.5 \mu \mathrm{m}$ CMOS & 2-OTA & $2-C$ & Yes & Yes & Yes & Yes & $>100 \mathrm{MHz}$ \\
\hline Ref. [20] & LM13600 (BJT) & 2-OTA & $2-C$ & Yes & Yes & Yes & Yes & $>10 \mathrm{MHz}$ \\
\hline Ref. [21] & ALA400 BJT & 5-CCCII & $2-C$ & Yes & Yes & Yes & Yes & $>10 \mathrm{MHz}$ \\
\hline \begin{tabular}{|l|} 
Ref. [22] \\
\end{tabular} & ALA400 BJT & 4-CCCII & $2-C$ & Yes & Yes & Yes & Yes & $>2 \mathrm{MHz}$ \\
\hline Ref. [24] & ALA400 BJT & 4-CCCII & $2-C$ & Yes & Yes & Yes & Yes & $>10 \mathrm{MHz}$ \\
\hline Ref. [26] & HFA3096 (BJT) & 2-CCCII & $2-C$ & Yes & Yes & Yes & Yes & $>100 \mathrm{MHz}$ \\
\hline Ref. [31] & $0.5 \mu \mathrm{m}$ CMOS & 2-CDTA & $2-C$ & No & Yes & Yes & No & $>100 \mathrm{MHz}$ \\
\hline Ref. [32] & $0.5 \mu \mathrm{m}$ CMOS & 2-CDTA & $2-C$ & Yes & Yes & Yes & Yes & $>10 \mathrm{MHz}$ \\
\hline Ref. [33] & $0.35 \mu \mathrm{m}$ CMOS & 3-CDTA & $1-R \& 2-C$ & Yes & No & Yes & No & $>10 \mathrm{MHz}$ \\
\hline \begin{tabular}{|l|} 
Ref. [37] \\
\end{tabular} & ALA400 BJT & 3-CFTA, 3-PCA & $1-R \& 2-C$ & No & Yes & Yes & Yes & $>10 \mathrm{MHz}$ \\
\hline Ref. [38] & AD844N, MAX435 & 3-CFTA, 3-CMI & 3-CFTA, 3-CMI & $1-R \& 2-C$ & Yes & Yes & Yes & $>10 \mathrm{MHz}$ \\
\hline Ref. [39] & AD844N, MAX435 & 3-CFTA & $1-R \& 2-C$ & Yes & Yes & Yes & Yes & $>10 \mathrm{MHz}$ \\
\hline \begin{tabular}{|l|} 
Ref. [40] \\
\end{tabular} & AD844N, MAX435 & 3-CFTA & $1-R \& 2-C$ & Yes & No & Yes & No & $>10 \mathrm{MHz}$ \\
\hline \begin{tabular}{|l|} 
Ref. [41] \\
\end{tabular} & $0.5 \mu \mathrm{m}$ CMOS & 3-CCFTA, 1-OTA & $2-C$ & No & Yes & Yes & Yes & $>100 \mathrm{MHz}$ \\
\hline \begin{tabular}{|l|} 
Ref. [42] \\
\end{tabular} & $0.35 \mu \mathrm{m}$ CMOS & 3-ZC-CFTA & $1-R \& 2-C$ & Yes & Yes & No & Yes & $>100 \mathrm{MHz}$ \\
\hline Ref. [43] & AD844N, MAX435 & 3-CFTA & $2-C$ & Yes & Yes & Yes & Yes & $>100 \mathrm{MHz}$ \\
\hline Ref. [44] & AD844N, MAX435 & 3-CFTA & $1-R \& 2-C$ & Yes & Yes & Yes & Yes & $>100 \mathrm{MHz}$ \\
\hline \begin{tabular}{|l|} 
Ref. [45] \\
\end{tabular} & ALA400 BJT & 3-CFTA & $2-C$ & Yes & Yes & Yes & Yes & $>100 \mathrm{MHz}$ \\
\hline Ref. [46] & $0.35 \mu \mathrm{m} \mathrm{CMOS}$ & 3-ZC-CFTA & $2-C$ & Yes & Yes & Yes & Yes & $>100 \mathrm{MHz}$ \\
\hline Ref. [47] & ALA400 BJT & 1-CFTA & $1-R \& 2-C$ & Yes & Yes & Yes & No & $>10 \mathrm{MHz}$ \\
\hline \begin{tabular}{|l|} 
Ref. [48] \\
\end{tabular} & $0.5 \mu \mathrm{m}$ CMOS & 1-CCFTA & $2-C$ & No & Yes & Yes & No & $>100 \mathrm{MHz}$ \\
\hline \begin{tabular}{|l|} 
Ref. [50] \\
\end{tabular} & CMOS & $1-\mathrm{CCII}$ & 3-R \& 2-C & No & No & No & No & $>10 \mathrm{MHz}$ \\
\hline \begin{tabular}{|l|} 
Ref. [51] \\
\end{tabular} & AD844N (BJT) & $1-\mathrm{CCII}$ & $2-R \& 2-C$ & No & Yes & No & Yes & $>10 \mathrm{MHz}$ \\
\hline Ref. [52] & AD844N (BJT) & 1-CFOA & $2-R \& 2-C$ & No & Yes & No & Yes & $>10 \mathrm{MHz}$ \\
\hline Ref. [53] & $0.35 \mu \mathrm{m} \mathrm{CMOS}$ & 1-CDTA & $1-R \& 2-C$ & No & No & No & No & $>10 \mathrm{MHz}$ \\
\hline \begin{tabular}{|l|} 
Ref. [54] \\
\end{tabular} & $0.5 \mu \mathrm{m}$ CMOS & 1-CDTA & 2-R \& 2-C & No & No & No & No & $>100 \mathrm{MHz}$ \\
\hline Ref. [55] & ALA400 BJT & 1-ССССТA & $2-C$ & Yes & Yes & Yes & Yes & $>3 \mathrm{MHz}$ \\
\hline
\end{tabular}

The bipolar implementation CCFTA that was used in this work is shown in Fig. 2. It should be noted that if CMOS implementation of CCFTA is required, the bipolar junction transistors in Fig. 2 can be replaced by MOS transistors counterparts. Assuming that transistors, $\mathrm{Q}_{1}$ to $\mathrm{Q}_{4}$, in Fig. 2 are identical, the resistance at $\mathrm{f}$-terminal $\left(R_{f}\right)$ can be expressed [56] as

$R_{f}=\frac{V_{T}}{2 I_{b 1}}$

where $\mathrm{V}_{\mathrm{T}}$ is the thermal voltage.
Assuming transistors $\mathrm{Q}_{16}$ and $\mathrm{Q}_{17}$ are identical, the transconductance gain $\left(g_{m}\right)$ can be expressed as

$g_{m}=\frac{I_{b 2}}{2 V_{T}}$

The multiple-output plus/minus CCFTA can be obtained by adding additional current mirrors and crosscoupled current mirrors to obtain plus- and minus-type outputs $\pm z c$ and $\pm x$ [24]. It should be noted from Fig. 2 that there are two parasitic parameters available for implementing universal filter, meaning that passive de- 
vices such as resistors are not required. Therefore the CCFTA-based universal filter can be tuned electronically. If Fig. 2 is implemented using CMOS technology, the values of $R_{f}$ and $g_{m}$ in (2) and (3), are proportional to the square root of the bias current. This, however, changes the electronic tunability of the CCFTA-based universal filter in the sense that the tuning range is no longer linear.

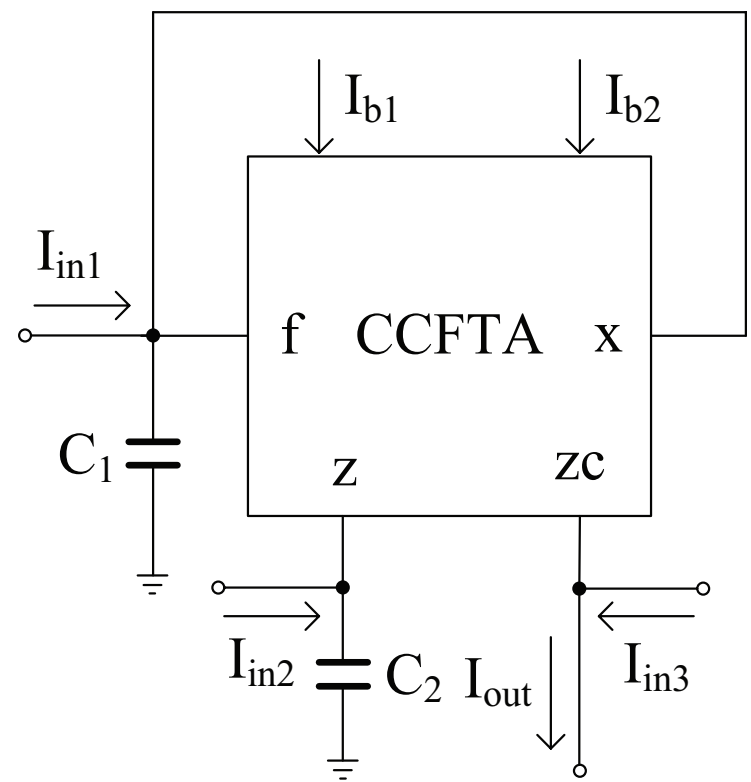

Figure 3: Proposed universal multifunction filter using CCFTA.

The proposed current-mode universal multifunction filter using minimum number of active and passive components is shown in Fig. 3. This filter is developed from a previously reported filter in [57]. The circuit consists of only one CCFTA and two grounded capacitors which is the main advantage of proposed circuit. It should be noted that the proposed circuit uses grounded capacitors which is ideal for IC implementation [49]. Assuming $\mathrm{I}_{\text {in } 1} \mathrm{I}_{\text {in } 2}$ and $\mathrm{I}_{\text {in3 }}$ are input currents, using nodal analysis and CCFTA characteristic given in (1), current output $\mathrm{I}_{\text {out }}$ of the proposed filter can be expressed as

$I_{\text {out }}=\frac{D(s) I_{i n 3}-g_{m} I_{i n 2}-s C_{2} I_{i n 1}}{D(s)}$

where $D(s)=s^{2} R_{f} C_{1} C_{2}+s C_{2}+g_{m}$.

From (4), the LP, BP, HP, BS and AP filters can be obtained as follows:

- $\quad$ The LP response can be obtained if $\mathrm{I}_{\text {in2 }}=\mathrm{I}_{\text {in }}$ and $\mathrm{I}_{\text {in } 1}=\mathrm{I}_{\text {in } 3}=0$.

- $\quad$ The BP response can be obtained if $\mathrm{I}_{\mathrm{in} 1}=\mathrm{I}_{\text {in }}$ and $\mathrm{I}_{\text {in2 }}=\mathrm{I}_{\text {in } 3}=0$.

- $\quad$ The HP response can be obtained if $\mathrm{I}_{\mathrm{in} 1}=\mathrm{I}_{\mathrm{in} 2}=\mathrm{I}_{\mathrm{in} 3}=\mathrm{I}_{\mathrm{in}}$.
- $\quad$ The BS response can be obtained if $\mathrm{I}_{\mathrm{in} 1}=\mathrm{I}_{\mathrm{in} 3}=\mathrm{I}_{\text {in }}$ and $\mathrm{I}_{\text {in2 }}=0$.

The AP response can be obtained if $2 \mathrm{I}_{\mathrm{in} 1}=\mathrm{I}_{\mathrm{in} 3}=\mathrm{I}_{\text {in }}$ and $\mathrm{I}_{\text {in } 2}=0$.

Therefore, the proposed filter in Fig. 3 can implement five standard filtering functions with a single topology. It should be noted that the realization requires no passive-matching condition and no inverted input signal. For obtaining HP, BS and AP responses, multiple- and/ or double-input signals are required, but which can be easily obtained with a multiple-output current follower circuit. However, compared with LP and BP responses, $H P, B S$ and AP responses may suffer from the input current mismatch because two identical input signals are required. This mismatch can disturb the operation of some responses, especially for obtaining the AP response when the condition of $2 \mathrm{I}_{\mathrm{in} 1}=\mathrm{I}_{\mathrm{in} 3}=\mathrm{I}_{\text {in }}$ is needed. This problem can be minimized by carefully designing the current follower. Also it should be noted that the current gains of the LP, HP and BP responses are equal to unity. If a filtering function with a current gain is required, additional active elements such as current amplifiers [58] are be needed. The use of current amplifier at the input avoids the problem of input impedance dependency on the frequency.

The peak frequency $\omega_{0}$ and quality of BP filter $Q=\omega_{0} / B W$ is usually related, where BW is the bandwidth. It should be noted that the relation of $\mathrm{Q}$ and $\mathrm{BW}$ is inverse, thus the higher Q, the narrower BW of BP filter. Meanwhile, the peak frequency $\omega_{0}$ for the LP and HP filters will also increase with increasing the value of $Q$. The parameters $\omega_{\mathrm{o}}$ and $\mathrm{Q}$ are calculated, respectively, as

$$
\begin{aligned}
& \omega_{o}=\sqrt{\frac{g_{m}}{C_{1} C_{2} R_{f}}} \\
& Q=\sqrt{R_{f} g_{m}\left(\frac{C_{1}}{C_{2}}\right)}
\end{aligned}
$$

Using (2) and (3), the parameters $\omega_{\mathrm{o}}$ and $\mathrm{Q}$ in (5) and (6) can be rewritten as

$$
\begin{aligned}
& \omega_{o}=\frac{1}{V_{T}} \sqrt{\frac{I_{b 1} I_{b 2}}{C_{1} C_{2}}} \\
& Q=\frac{1}{2} \sqrt{\frac{I_{b 2}}{I_{b 1}}\left(\frac{C_{1}}{C_{2}}\right)}
\end{aligned}
$$

Letting $\mathrm{I}_{\mathrm{b} 1}=\mathrm{I}_{\mathrm{b} 2}=\mathrm{I}_{\mathrm{b}^{\prime}}$ (7) and (8) simplify to 
$\omega_{o}=\frac{I_{b}}{V_{T}} \sqrt{\frac{1}{C_{1} C_{2}}}$

$Q=\frac{1}{2} \sqrt{\frac{C_{1}}{C_{2}}}$

From (9) and (10), the parameter $\omega_{\circ}$ can be tuned by adjusting the value of $\mathrm{I}_{\mathrm{b}}$ whereas the parameter $\mathrm{Q}$ can be given by adjusting the ratio of $C_{1} / C_{2}$. Therefore, the proposed filter can be controlled orthogonally for parameters $\omega_{0}$ and $Q$, but it cannot be controlled independently. It should be noted from (9) that if the bipolar implementation of CCFTA is used, parameter $\omega$ can be controlled linearity. For IC implementation, adjusting the value of capacitor for obtaining desired high Q-value is difficult, but it can be resolved using a capacitor bank formed by parallelly connected capacitors with switches. The value of the capacitor can then be varied by setting the switches.

\section{Non-ideal analysis}

In this section, the effects of CCFTA non idealities on the proposed filter performances have been analyzed. Taking into account the non-idealities of CCFTA, the CCFTA non-idealities can be obtained from

$$
\left(\begin{array}{c}
I_{z}^{\prime} \\
I_{z c}^{\prime} \\
I_{x}^{\prime} \\
V_{f}^{\prime}
\end{array}\right)=\left(\begin{array}{cccc}
0 & 0 & 0 & \beta_{z} \\
0 & 0 & 0 & \beta_{z c} \\
g_{m} & 0 & 0 & 0 \\
0 & 0 & 0 & R_{f}
\end{array}\right)\left(\begin{array}{c}
V_{z} \\
V_{z c} \\
V_{x} \\
I_{f}
\end{array}\right)
$$

where $\beta_{z}$ and $\beta_{z c}$ are respectively the non-ideal current transfer gains between $f-z$ and $f-z c$ terminals of the CCFTA.

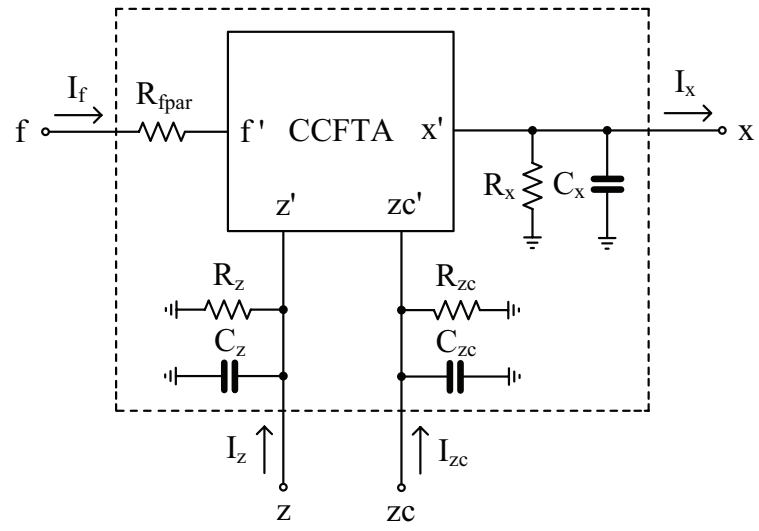

Figure 4: CCFTA with its parasitic components.
The non-ideal CCFTA symbol including various parasitic elements is shown in Fig. 4. The f-terminal exhibits parasitic serial resistance $R_{\text {fpar' }}$ the $z$-terminal exhibits high-value parasitic resistances $R_{z}$ in parallel with lowvalue parasitic capacitance $C_{z^{\prime}}$ the $z_{c}$-terminal exhibits high-value parasitic resistance $R_{z c}$ in parallel with lowvalue parasitic capacitance $C_{z c}$ and the $x$-terminal exhibits high-value parasitic resistance $R_{x}$ in parallel with low-value parasitic capacitance $C_{x}$.

The non-ideality of transconductance gain $g_{m n}$ of CCFTA can be expressed as

$g_{m n}=\frac{g_{m} \omega_{g}}{s+\omega_{g}}$

where $\omega_{\mathrm{g}}$ denotes the first-order pole of the transconductance amplifier. In the frequency range of our interest, $g_{m n}$ is modified to [59]

$g_{m n} \cong g_{m}(1-\mu s)$

where $\mu=1 / \omega_{g}$.

Equations (11), (13) now result in Fig. 4, the current I of Fig. 3 can be given by

$I_{\text {out }}=\frac{D(s) I_{i n 3}-\beta_{z} R_{x} g_{m n} I_{i n 2}-\beta_{z c} R_{x}\left(s C_{2}^{\prime} R_{z}+1\right) I_{i n 1}}{D(s)}$

$$
\begin{aligned}
D(s)= & \left(s^{2} C_{1}^{\prime} C_{2}^{\prime} R_{x} R_{z}+s C_{1}^{\prime} R_{x}+s C_{2}^{\prime} R_{z}+1\right) R_{f}+ \\
& +\left(s C_{2}^{\prime} R_{z}+1\right) R_{x}+g_{m n} R_{x} R_{z} \\
= & s^{2} C_{1}^{\prime} C_{2}^{\prime} R_{f} R_{x} R_{z}+s C_{1}^{\prime} R_{f} R_{x}+s C_{2}^{\prime} R_{f} R_{z}+ \\
& +R_{f}+s C_{2}^{\prime} R_{z} R_{x}+R_{x}+g_{m n} R_{x} R_{z} \\
= & s^{2}\left(C_{1}^{\prime} C_{2}^{\prime} R_{f} R_{x} R_{z}\right)+s\left(C_{1}^{\prime} R_{f} R_{x}+C_{2}^{\prime} R_{f} R_{z}+C_{2}^{\prime} R_{z} R_{x}\right)+ \\
& +\left(g_{m n} R_{x} R_{z}+R_{f}+R_{x}\right)
\end{aligned}
$$

Letting $R_{f}<<R_{x}$ and $R_{f}<<R_{z}$, (15) becomes

$$
\left.\begin{array}{rl}
D(s) & =s^{2}+s\left(\frac{1}{C_{2}^{\prime} R_{z}}+\frac{1}{C_{1}^{\prime} R_{x}}+\frac{1}{C_{1}^{\prime} R_{f}}\right)+\frac{g_{m n}}{C_{1}^{\prime} C_{2}^{\prime} R_{f}} \\
& =s^{2}+s \frac{1}{C_{1}^{\prime} R_{f}}+\frac{g_{m n}}{C_{1}^{\prime} C_{2}^{\prime} R_{f}}
\end{array}\right\}
$$

where $C_{1}^{\prime}=C_{1} \| C_{x}$ and $C_{2}^{\prime}=C_{2} \| C_{z}$.

From (16) we can see that CCFTA non-idealities affect the circuit characteristics which depart from ideal values. To prevent significant errors, the value of the capacitors $C_{1}$ and $C_{2}$ should be selected to meet the con- 
ditions $C_{1} \gg C_{x}$ and $C_{2}>>C_{z}$. The non-ideal values of parameters $\omega_{\mathrm{o}}$ and $\mathrm{Q}$ can be expressed as

$$
\begin{aligned}
& \omega_{o}=\sqrt{\frac{g_{m n}}{C_{1}^{\prime} C_{2}^{\prime} R_{f}}} \\
& Q=\sqrt{R_{f} g_{m n}\left(\frac{C_{1}^{\prime}}{C_{2}}\right)}
\end{aligned}
$$

It should be noted from (17) and (18) that the parameters $\omega_{0}$ and $Q$ are slightly changed by the non-idealities of the CCFTA. However, these effects can be compensated by adjusting the $g_{m}$-value. The active and passive sensitivities of the filter parameters are

$S_{g_{m n}}^{\omega_{o}}=-S_{C_{1}}^{\omega_{o}}=-S_{C_{2}^{\prime}}^{\omega_{o}}=-S_{R_{f}}^{\omega_{o}}=0.5$

$S_{R_{f}}^{Q}=S_{g_{m n}}^{Q}=S_{R_{z}}^{Q}=S_{C_{1}^{\prime}}^{Q}=-S_{C_{2}^{\prime}}^{Q}=0.5$

From (19)-(20) we can see that the incremental sensitivities of the active and passive parameters do not exceed 1 in magnitude. Hence, the proposed filter offers low active and passive sensitivities.

\section{Application to sixth-order filters}

It is well-known that biquadratic filters can be used to realize high-order filters [2]. To confirm the applicability of the proposed universal biquadratic filter, highorder filters using the proposed biquadratic filter are designed. The structures of high-order filters such as sixth-order Butterworth LP, HP and BP filters have been designed. Sixth-order Butterworth LP filter can be designed by cascading tree second-order LP filters. In case of second-order HP filter, additional multiple-input current follower (CF) is required. Fig. 5(a) shows the block diagram of a second-order HP filter. The bipolar implementation of multiple-output CF is shown in Fig. 5(b). Sixth-order Butterworth BP filter can be obtained by cascading a sixth-order Butterworth HP filter and a sixth-order Butterworth LP filter. The block diagram is depicted in Fig. 6. To obtain a sixth-order Butterworth LP and HP characteristics, the filters have been designed using Tables 2 and 3. From Table 2, HP filter is designed for the cut-off frequency of $1 \mathrm{MHz}$ while the LP filter is designed for the cut-off frequency of $3 \mathrm{MHz}$. Using the bias currents and capacitor-values as shown in Tables 2 and 3, sixth-order Butterworth BP filter can be obtained with the bandwidth of $2 \mathrm{MHz}$. (a)

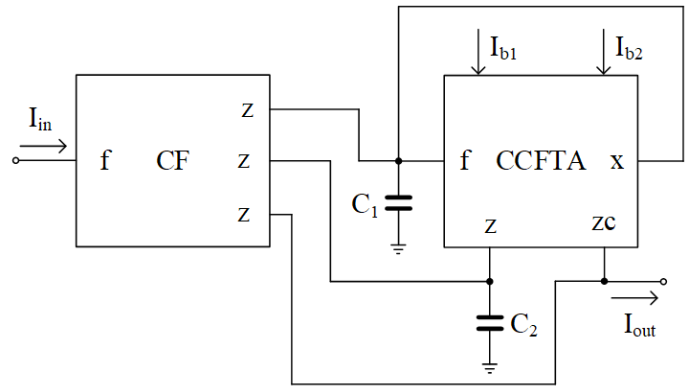

(a)

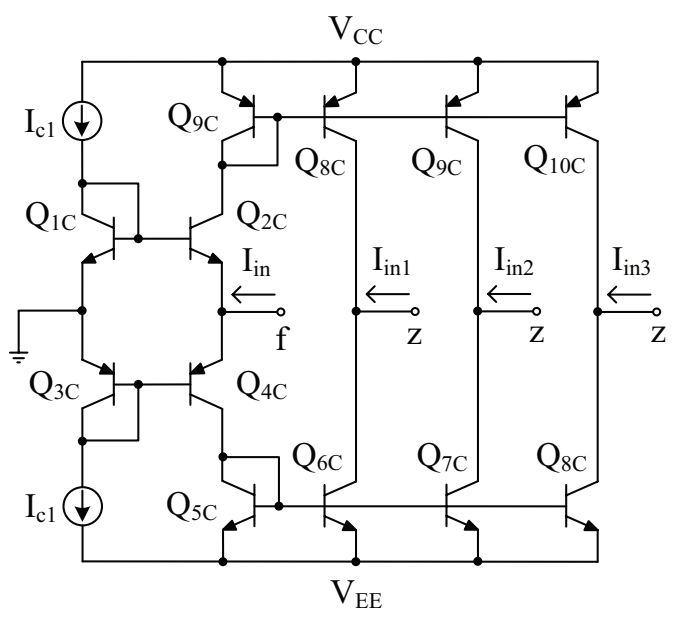

Figure 5: (a) second-order high-pass filter, (b) multipleoutput current follower.

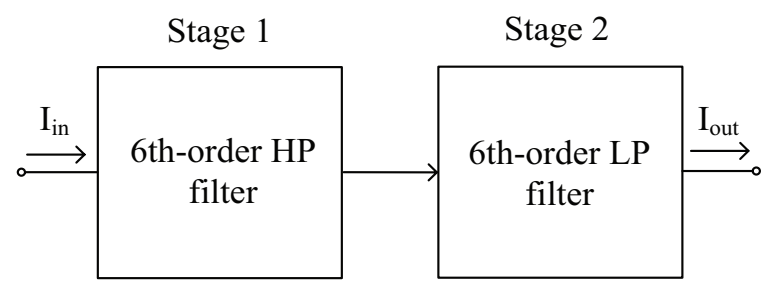

Figure 6: Sixth-order band-pass Butterworth filter.

Table 2: Parameters for sixth-order

Butterworth

\begin{tabular}{|c|c|}
\hline Second-order LP filter & Value $\left(f_{o}=3 \mathrm{MHz}\right)$ \\
\hline $\begin{array}{l}\text { Stage } 1 \\
(\mathrm{FSF}=1.000, \mathrm{Q}=0.5177)\end{array}$ & $\begin{array}{c}\mathrm{Ib}_{1}=\mathrm{Ib}_{2}=50.7 \mu \mathrm{A} \\
\mathrm{C}_{1}=107 \mathrm{pF} \\
\mathrm{C}_{2}=100 \mathrm{pF}\end{array}$ \\
\hline $\begin{array}{l}\text { Stage } 2 \\
(F S F=1.000, Q=0.7071)\end{array}$ & $\begin{array}{c}\mathrm{Ib}_{1}=\mathrm{Ib}_{2}=69.3 \mu \mathrm{A} \\
\mathrm{C}_{1}=200 \mathrm{pF} \\
\mathrm{C}_{2}=100 \mathrm{pF}\end{array}$ \\
\hline $\begin{array}{l}\text { Stage } 3 \\
(F S F=1.000, Q=1.9320)\end{array}$ & $\begin{array}{c}\mathrm{Ib}_{1}=\mathrm{Ib}_{2}=94.68 \mu \mathrm{A}, \\
\mathrm{C}_{1}=746.5 \mathrm{pF}, \\
\mathrm{C}_{2}=50 \mathrm{pF}\end{array}$ \\
\hline
\end{tabular}
LP filter. 
Table 3: Parameters for sixth-order Butterworth HP filter.

\begin{tabular}{|l|c|}
\multicolumn{1}{|c|}{ Second-order HP filter } & Value $\left(\mathrm{f}_{\mathrm{o}}=1 \mathrm{MHz}\right)$ \\
\hline Stage 1 & $\mathrm{Ib}_{1}=\mathrm{Ib}_{2}=33.79 \mu \mathrm{A}$, \\
(FSF $=1.000, \mathrm{Q}=0.5177)$ & $\mathrm{C}_{1}=214 \mathrm{pF}$, \\
& $\mathrm{C}_{2}=200 \mathrm{pF}$ \\
\hline Stage 2 & $\mathrm{Ib}_{1}=\mathrm{Ib}_{2}=46.2 \mu \mathrm{A}$, \\
(FSF $=1.000, \mathrm{Q}=0.7071)$ & $\mathrm{C}_{1}=400 \mathrm{pF}$, \\
& $\mathrm{C}_{2}=200 \mathrm{pF}$ \\
\hline Stage 3 & $\mathrm{Ib}_{1}=\mathrm{Ib}_{2}=126.2 \mu \mathrm{A}$, \\
(FSF = 1.000, Q = 1.9320) & $\mathrm{C}_{1}=2.98 \mathrm{nF}$, \\
& $\mathrm{C}_{2}=200 \mathrm{pF}$ \\
\hline
\end{tabular}

\section{Simulation results}

The proposed filters are verified with PSPICE simulations. The CCFTA in Fig. 2 was implemented with bipolar transistor array HFA3096 [60]. The supply voltages were $\mathrm{V}_{\mathrm{CC}}=-\mathrm{V}_{\mathrm{EE}}=3 \mathrm{~V}$. Simulated performance of CCFTA is given in Table 4.

Fig. 7 depicts simulated frequency responses of $L P, B P, H P$ and $B S$ filters with $I_{b 1}=I_{b 2}=90 \mu A, C_{1}=3000 p F$ and $C_{2}=$ $100 \mathrm{pF}$, resulting in a natural angular frequency $f_{\mathrm{o}} \cong 1 \mathrm{MHz}$ and $Q \cong 2.73$. Fig. 8 shows simulated frequency responses of the magnitude and phase characteristics of the AP filter at $f_{\text {o }} \cong 1 \mathrm{MHz}$. It is clear from Figs. 7 and 8 that the proposed filter performs five standard filtering functions such as LP, BP, HP BS and AP filters with a single topology. Fig. 9 shows the simulated frequency response of a BP filter when the bias currents $I_{b}$ (i.e., $I_{b}=I_{b 1}=I_{b 2}$ ) were simultaneously adjusted to $20,50,100$ and $200 \mu \mathrm{A}$, respectively, while keeping $C_{1}=3000 \mathrm{pF}$ and $C_{2}=100 \mathrm{pF}$ for a constant $\mathrm{Q} \cong 2$.73. This simulation result confirms (9).

Table 4: Simulated parameters of CCFTA.

\begin{tabular}{|l|c|}
\multicolumn{1}{c|}{ Parameters } & Value \\
\hline Technology & Bipolar \\
\hline Supply voltage & $\pm 3 \mathrm{~V}$ \\
\hline $\mathrm{R}_{\mathrm{f}}\left(\mathrm{I}_{\mathrm{b} 1}=1-250 \mu \mathrm{A}\right)$ & $12 \mathrm{k}$ to $52[\Omega]$ \\
\hline $\mathrm{g}_{\mathrm{m}}\left(\mathrm{I}_{\mathrm{b} 2}=1-250 \mu \mathrm{A}\right)$ & $21 \mu$ to $51 \mathrm{~m}[\mathrm{~A} / \mathrm{V}]$ \\
\hline Current gain $\left(\mathrm{I}_{\mathrm{z}} / \mathrm{I}_{\mathrm{f}}\right)$ & 0.991 \\
\hline Current gain $\left(\mathrm{I}_{\mathrm{zc}} \mathrm{I}_{\mathrm{f}}\right)$ & 0.991 \\
\hline$-3 \mathrm{~dB}$ bandwidth: $\mathrm{I}_{\mathrm{z}} / \mathrm{I}_{\mathrm{f}}$ & \\
$\mathrm{I}_{\mathrm{zc}} / \mathrm{I}_{\mathrm{f}}$ & $191 \mathrm{MHz}$ \\
$\mathrm{I}_{\mathrm{x}} / \mathrm{I}_{\mathrm{f}}\left(\mathrm{Ib}=\mathrm{Ib} \mathrm{b}_{2}=100 \mu \mathrm{A}\right.$, & $191 \mathrm{MHz}$ \\
$\left.\mathrm{R}_{\mathrm{z}}=495 \Omega\right)$ & $66 \mathrm{MHz}$ \\
\hline $\mathrm{R}_{\mathrm{z}} / / \mathrm{C}_{\mathrm{z}} @ \mathrm{I}_{\mathrm{b} 1}=100 \mu \mathrm{A}$ & $63 \mathrm{k} \Omega / / 0.792 \mathrm{pF}$ \\
$\mathrm{R}_{\mathrm{zc}} / / \mathrm{C}_{\mathrm{zc}} @ \mathrm{I}_{\mathrm{b} 1}=100 \mu \mathrm{A}$ & $184 \mathrm{k} \Omega / / 0.304 \mathrm{pF}$ \\
$\mathrm{R}_{\mathrm{f}} / / \mathrm{L}_{\mathrm{f}} @ \mathrm{I}_{\mathrm{b} 1}=100 \mu \mathrm{A}$ & $128 \Omega / / 0.127 \mathrm{nH}$ \\
$\mathrm{R}_{\mathrm{x}} / / \mathrm{C}_{\mathrm{x}} @ \mathrm{I}_{\mathrm{b} 2}=100 \mu \mathrm{A}$ & $363 \mathrm{k} \Omega / / 0.208 \mathrm{pF}$ \\
\hline Static power dissipation & \\
$@ \mathrm{I}_{\mathrm{b} 1}=\mathrm{I}_{\mathrm{b} 2}=1 \mu \mathrm{A}$ & $43.5 \mu \mathrm{W}$ \\
$@ \mathrm{I}_{\mathrm{b} 1}=\mathrm{I}_{\mathrm{b} 2}=250 \mu \mathrm{A}$ & $108 \mathrm{~mW}$ \\
\hline
\end{tabular}

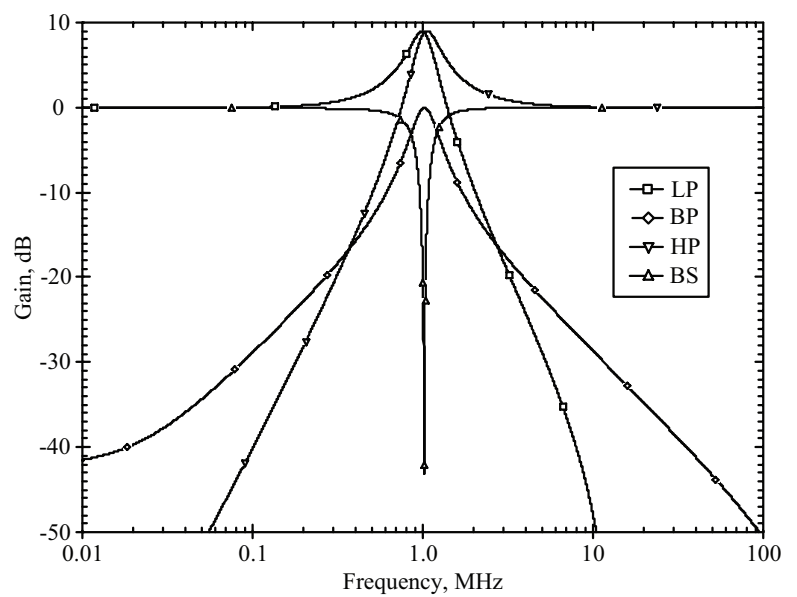

Figure 7: Simulated frequency responses of $L P, B P, H P$ and BS filters.

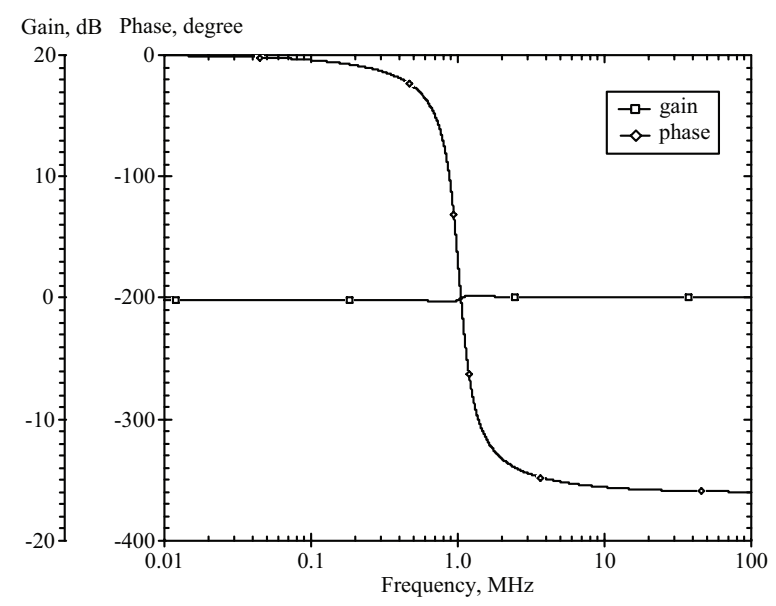

Figure 8: Simulated magnitude and phase response of an AP filter.

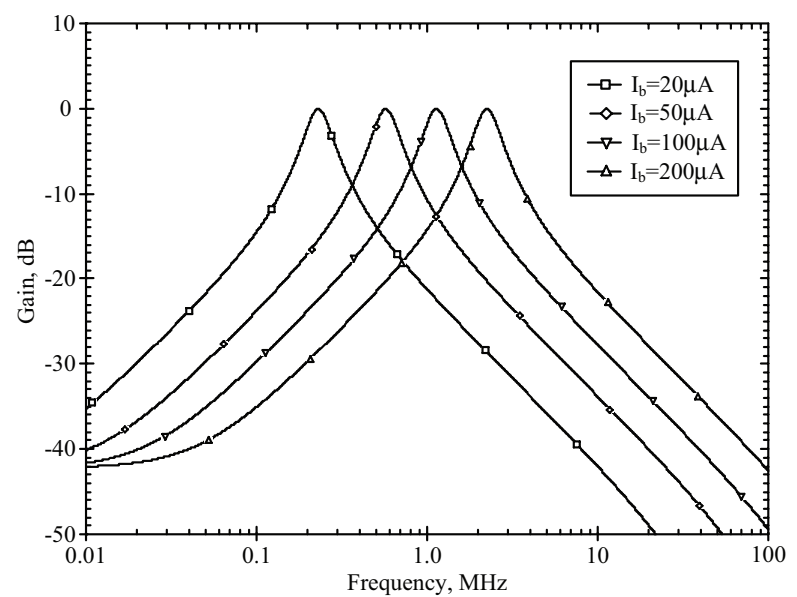

Figure 9: Frequency responses of a BP filter when $I_{b}$ is varied. 


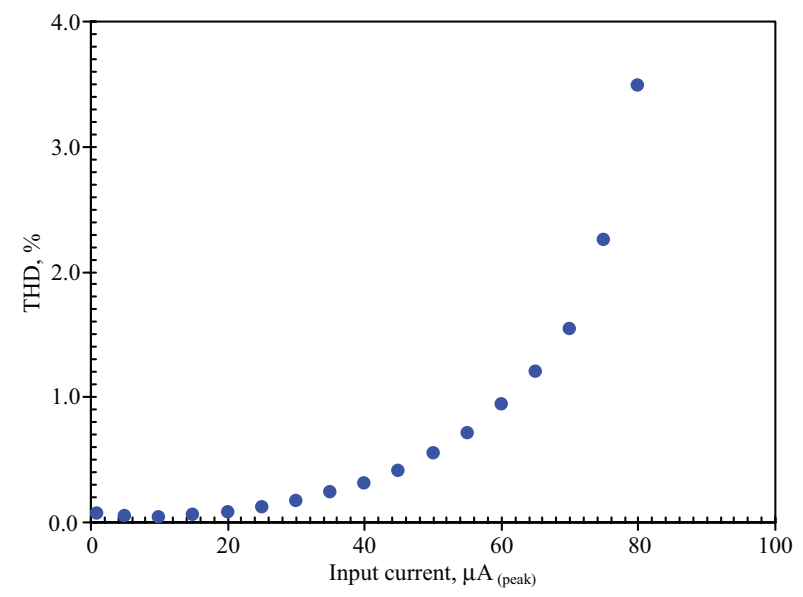

Figure 10: Dependence of the output harmonic distortion of LP filter on the input current amplitude for a 100 $\mathrm{kHz}$ input signal.

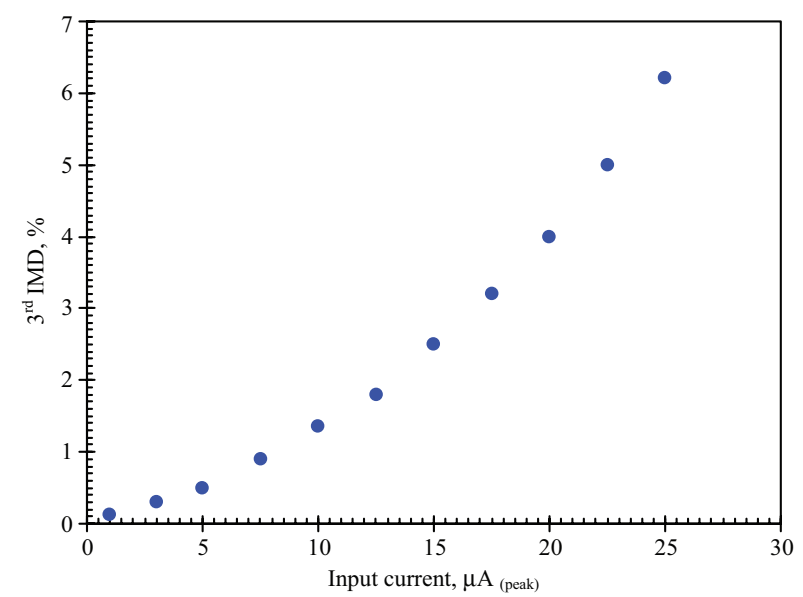

Figure 11: Dependence of the 3rd IMD of BP filter on input current amplitudes.

In order to test the linearity of the proposed filter, two methods were used; single-tone and two-tone tests. A single-tone test was performed by applying a sinusoidal signal of $f_{\mathrm{o}}=100 \mathrm{kHz}$ at the input of a LP filter. The dependence of the output harmonic distortion on the input amplitude is shown in Fig. 10. From this result, the THD was about $1.2 \%$ when the input signal was $65 \mu \mathrm{A}$ (peak) and it increases to $3.49 \%$ when input signal increases to $80 \mu \mathrm{A}$ (peak). A two-tone test was performed on the BP filter by applying two closely spaced tones with equal input signal amplitudes simultaneously at the input of BP filter. Fig. 11 shows the dependence of the $3^{\text {rd }}$ IMD (intermodulation distortion) of BP filter on the input signals amplitudes. The two closely space tones with $f_{1}=0.8 \mathrm{MHz}$ and $f_{2}=1.2 \mathrm{MHz}$ had the same amplitude. It shows that the 3 rd IMD is $6.2 \%$ for the input signals amplitude of $25 \boldsymbol{\mu A}$ (peak). The proposed filter was investigated using a Monte-Carlo analysis. The simulation test was the fluctuation of $f_{0}$ changes caused by the deviation of the capacitors. In this test, the BP filter was simulated for $5 \%$ tolerances of capacitors $C_{1}$ and $C_{2}$ at $f_{\mathrm{o}}=1 \mathrm{MHz}, \mathrm{Q} \cong 2.73$ and 200 Gaussian distribution runs. Fig. 12 shows the derived histogram of $f_{\text {。 }}$. The standard deviation $(\sigma)$ of $f$ was $31.96 \mathrm{kHz}$ and the minimal and maximal values of $f_{\mathrm{o}}$ were $0.928 \mathrm{MHz}$ and 1.1 $\mathrm{MHz}$, respectively.

From (9) we can see that $\omega_{\mathrm{o}}$ depends on $\mathrm{V}_{\mathrm{T}}$ which in turn depends on the absolute temperature. Thus temperature stability of the proposed filter's $\omega_{0}$ of the proposed filter on parameter $\omega_{0}$ was investigated by varying temperature from $0^{\circ}$ to $75^{\circ}$. The simulated frequency responses of the BP filter corresponding to different temperatures are depicted in Fig. 13.

When temperature varied between 0 and $75^{\circ}$, the corresponding $f_{\mathrm{o}}$ varied between $1.1 \mathrm{MHz}$ and $0.879 \mathrm{MHz}$. This effect is expressed by (7). This problem can be solved by using a bias current source with the current proportional to the absolute temperature [61].

Three sixth-order Butterworth filters were also tested using parameters given in Tables 2 and 3. Simulated frequency responses of sixth-order Butterworth LP and HP filters are depicted in Figs. 14 and 15, respectively. The cut-off frequencies of $3 \mathrm{MHz}$ and $1 \mathrm{MHz}$ were obtained. The sixth-order Butterworth BP filter was simulated and the result is depicted in Fig. 16. The bandwidth (BW) of $2 \mathrm{MHz}$ was expressed. The power consumptions for sixth-order Butterworth LP, HP and BP filters were $9.05 \mathrm{~mW}, 18.5 \mathrm{~mW}$ and $82.4 \mathrm{~mW}$, respectively.

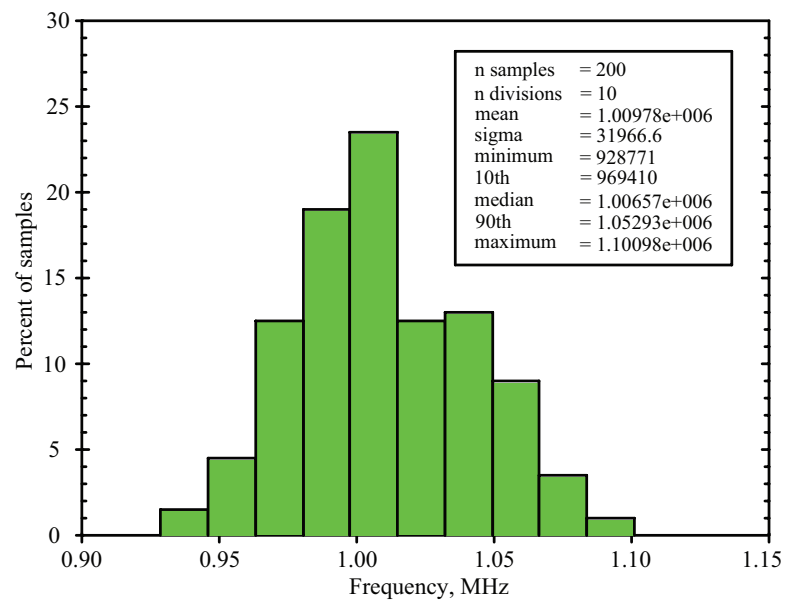

Figure 12: Histogram of Monte-Carlo analysis for BP filter with a $5 \%$ variation of capacitors $C_{1}$ and $C_{2}$. 


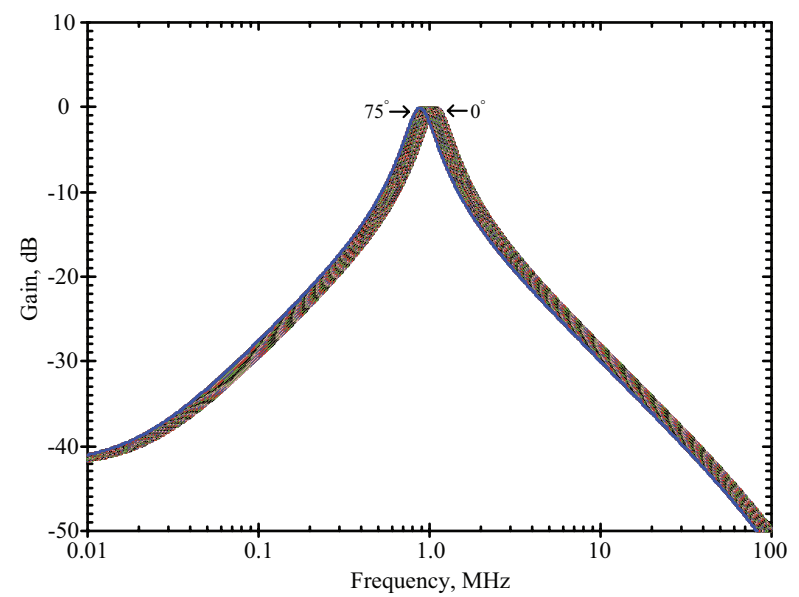

Figure 13: Simulated frequency responses of the BP filter for different temperatures.

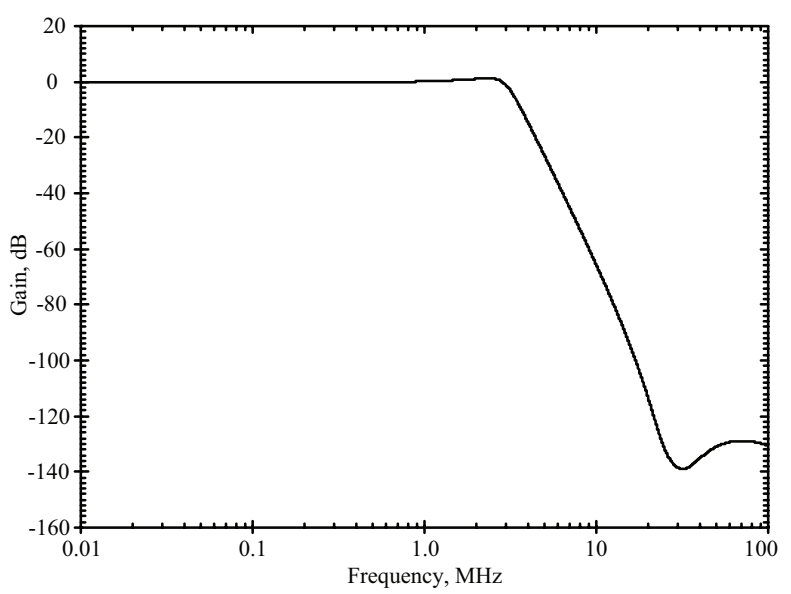

Figure 14: Simulated magnitude response of the sixthorder Butterworth LP filter.

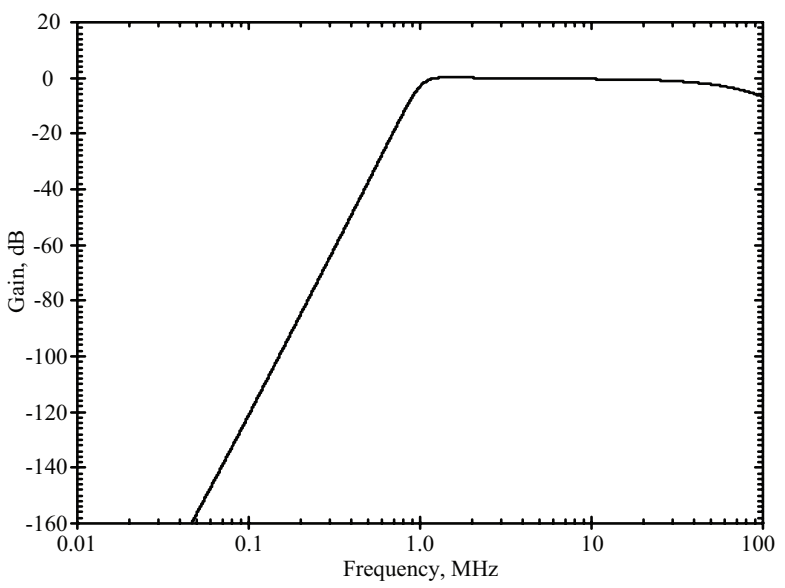

Figure 15: Simulated magnitude response of the sixthorder Butterworth HP filter.

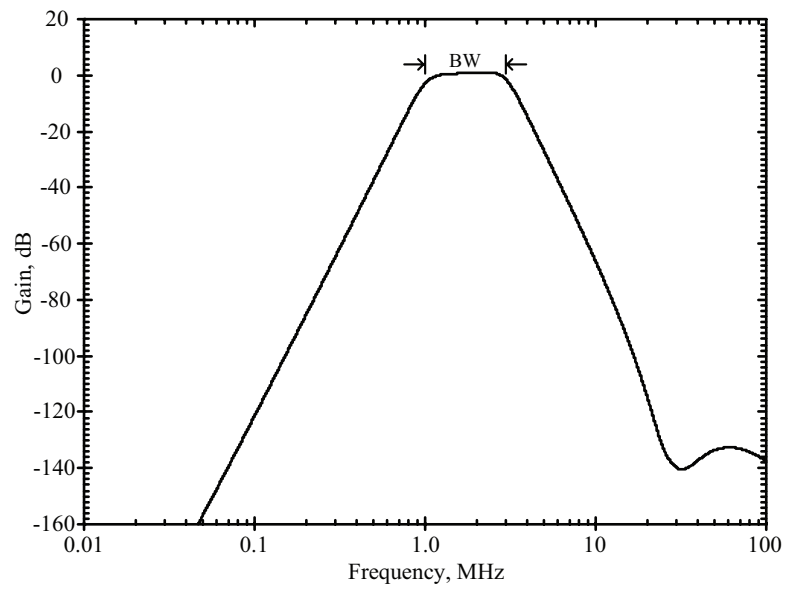

Figure 16: Simulated magnitude response of the sixthorder Butterworth BP filter.

\section{Conclusions}

In this paper, a new electronically tunable currentmode multifunction biquadratic filter employing one CCFTA and two grounded capacitors is presented. The proposed filter offers the following properties: (i) employment of grounded capacitors which is ideal for IC implementation; (ii) ability to implement LP, BP, HP, BS and AP filter responses without inverted input signals and passive component-matching conditions; (iii) orthogonal control of parameters $\omega_{\mathrm{o}}$ and $\mathrm{Q}$; (iv) currentcontrolled of parameter $\omega_{\mathrm{o}} ;(\mathrm{v})$ high output impedance output which can be directly connected to next the stage and (vi) low active and passive sensitivities. The proposed biquadratic filter has been used to implement high-order filters such as sixth-order Butterworth LP, HP and BP filters to confirm the applicability of the presented structure. Simulation results confirm the performance of the proposed filters.

\section{Acknowledgments}

This work was supported by King Mongkut's Institute of Technology Ladkrabang under grant KREF026201. Research described in this paper was also financed by the National Sustainability Program under grant LO1401. For the research, infrastructure of the SIX Center was used.

\section{References}

1. C. K. Alexander, M. N. O. Sadiku, Fundamental of Electric Circuits, New York, McGraw-Hill, 2004. 
2. R. Schaumann, M. S. Ghausi, K. R. Laker, Design of Analog Filter: Passive, Active RC, and Switched Capacitor, New Jersey, Prentice Hall, 1990.

3. A. M. Soliman, "A new filter configuration using current feedback op-amp," Microelectronics Journal, vol. 29, pp. 409-419, 1998.

https://doi.org/10.1016/S0026-2692(97)00025-6

4. C. M. Chang, M. J. Lee, "Voltage-mode multifunction filter with single input and three outputs using two compound current conveyors," IEEE Transactions on Circuits and Systems, Fundamental Theory and Applications, vol. 46, pp. 1364-1365, 1999. https://doi.org/10.1109/81.802827

5. S. Manaei, O. Cicekoglu, H. Kuntman, G. Dundar, O. Cerid, "New realization of current-mode and voltage-mode multifunction filters without external passive elements," International Journal of Electronics and Communications, vol. 57, pp. 6369, 2003.

https://doi.org/10.1078/1434-8411-54100141

6. C. M. Chang, H. P. Chen, "Single FDCCII-based tunable universal voltage-mode filter," Circuits Systems and Signal Processing, vol.24, pp. 221-227, 2005.

https://doi.org/10.1007/s00034-004-0422-7

7. N. A. Shah, M. F. Rather, S. Z. Iqbal, "CFA-based three input and two outputs voltage-mode universal filter," Indian Journal of Pure \& Applied Physics, vol. 43, pp. 636-639, 2005.

8. W. T. Lee, Y. Z. Liao, "New voltage-mode high-pass, band-pass and low-pass filter using DDCC and OTAs," International Journal of Electronics and Communications, vol. 62, pp. 701-704, 2008. https://doi.org/10.1016/j.aeue.2007.08.007

9. M. Kumngern, B. Knobnob, K. Dejhan, “Electrically tunable high-input impedance voltagemode universal biquadratic filter based on simple CMOS OTAs," International Journal of Electronics and Communications, vol.64, pp.934-939, 2010. https://doi.org/10.1016/j.aeue.2009.07.015

10. A. Abaci, E. Yuce, "Second-order voltage-mode universal filters using two DVCCs, two grounded capacitors and four resistors," Journal of Circuits, Systems and Computers vol. 25, 2016. https://doi.org/10.1142/S0218126616501541

11. D. Singh, N. Afzal, "Fully digitally programmable voltage mode universal filter," Analog Integrated Circuits and Signal Processing, vol. 81, pp 741750, 2014. https://doi.org/10.1007/s10470-014-0418-6

12. W. Jaikla, D. Biolek, S. Siripongdee, J. Bajer, "High input impedance voltage-mode biquad filter using VD-DIBAs," Radioengineering, vol. 23, pp. 914921, 2014.
13. M. T. Abuelma'atti, A. M. Shabra, "A novel current conveyor-based universal current-mode filter," Microelectronics Journal, vol. 27, pp. 471-475, 1996. https://doi.org/10.1016/0026-2692(95)00108-5

14. C. A. Papazoglou, C. A. Karybakas, "Noninteracting electronically tunable CCII-based current-mode biquadratic filters," IEE Proceeding-Circuit Device Systems, vol. 144, pp. 178-184, 1997. https://doi.org/10.1049/ip-cds:19971078

15. S. Ozoguz, A. Toker, O. Cicekoglu, "New currentmode universal filters using only four (CCII+)s," Microelectronics Journal, vol. 30, pp. 255-258, 1999. https://doi.org/10.1016/S0026-2692(98)00114-1

16. J.-W. Horng, "Voltage/current-mode universal biquadratic filter using single CCII+," Indian Journal of Pure \& Applied Physics, vol. 48, pp. 749-756, 2010.

17. F. Kacar, A. Yesil, H. Kuntman, "Current-mode universal filters employing single FDCCII," Radioengineering, vol. 21, pp. 1269-1278, 2012.

18. D. R. Bhaskar, A. K. Singh, R. K. Sharma, R. Senani, "New OTA-C universal current-mode trans-admittance biquads," IEICE Electronics Express, vol.2, pp. 8-13, 2005.

https://doi.org/10.1587/elex.2.8

19. D. Biolek, V. Biolkova, Z. Kolka, "Universal currentmode OTA-C KHN biquad," International Journal of Electronics, Circuits and Systems, vol. 1, pp. 214-217, 2007.

20. C. M. Chang, S. K. Pai, "Universal current-mode OTA-C biquad with the minimum components," IEEE Transactions on Circuits and Systems, Fundamental Theory and Applications, vol. 47, pp. 12351238, 2000.

https://doi.org/10.1109/81.873877

21. S. Minaei, S. Turkoz, "Current-mode electronically tunable universal filter using only plus-type current controlled conveyors and grounded capacitors," ETRI Journal, vol. 26, pp. 292-296, 2004. https://doi.org/10.4218/etrij.04.0103.0146

22. S. Minaei, E. Yuce, "Current-mode active-c filter employing reduced number of CCCII+s," Journal of Circuits, Systems and Computers vol. 16, pp. 507-516, 2007. https://doi.org/10.1142/S0218126607003782

23. C. Wang, H. Liu, Y. Zhao, "A new current-mode current-controlled universal filter based on CCCII( \pm )," Circuits Systems and Signal Processing, vol. 27, pp. 673-682, 2008. https://doi.org/10.1007/s00034-008-9050-y

24. M. Kumngern, W. Jongchanachavawat, K. Dejhan, "New electrically tunable current-mode universal biquard filter using translinear current conveyors," International Journal of Electronics, vol. 97, pp. 511-523, 2010.

https://doi.org/10.1080/00207210903486823 
25. N. Pandey, S. K. Paul, "Mixed mode universal filter," Journal of Circuits, Systems and Computers, vol. 22, 2013. https://doi.org/10.1142/S0218126612500648

26. M. Kumngern, F. Khateb, P. Phasukkit, S. Tungjitkusolmun, S. Junnapiya, "ECCCII-Based CurrentMode Universal Filter with Orthogonal Control of $\omega_{\mathrm{o}}$ and Q," Radioengineering, vol. 23, pp. 687-696, 2014.

27. G. W. Roberts, A. S. Sedra, All-current-mode frequency selective circuits, Electronics Letters, vol. 25, pp. 759-761, 1989.

https://doi.org/10.1049/el:19890513

28. C. Toumazou, F.J. Lidgey, D. G. Haigh, F. J. Lidgey, Analogue IC design: the current-mode approach, Peter Peregrinus, 1990.

29. D. Biolek, "CDTA-building block for current-mode analog signal processing," in Proceedings of the ECCTD'03, 2003, III, pp. 397-400.

30. C. Acar, S. Ozoguz, "A new versatile building block: current differencing buffered amplifier suitable for analog signal-processing filters," Microelectronics Journal, vol. 30, pp. 157-160, 1999. https://doi.org/10.1016/S0026-2692(98)00102-5

31. A. U. Keskin, D. Biolek, E. Hancioglu, V. Biolkova, "Current-mode KHN filter employing current differencing transconductance amplifiers," International Journal of Electronics and Communications, vol. 60, pp. 443-446, 2006.

https://doi.org/10.1016/j.aeue.2005.09.003

32. A. Uygur, H. Kuntman, "Seventh-order elliptic video filter with $0.1 \mathrm{~dB}$ pass band ripple employing CMOS CDTAs," International Journal of Electronics and Communications, vol. 61, pp. 320-328, 2007. https://doi.org/10.1016/j.aeue.2006.06.002

33. N. A. Shah, M. Quadri, and S. Z. Iqbal, "Three input one output current-mode cascadable universal filter employing CDTAs," Journal of Active and Passive Electronic Devices, vol. 4, pp. 347-352, 2009.

34. D. Biolek, V. Biolkova, Z. Kolka, "Single-CDTA (current differencing transconductance amplifier) current-mode biquad revisited," WSEAS Transactions on Electronics, vol. 5, pp. 250-256, 2008.

35. W. Tangsrirat, " $\mathrm{G}_{\mathrm{m}}$-realization of controlled-gain current follower transconductance amplifier," The Scientific World Journal, vol. 2013, Article ID 201565, 8 pages:

http://dx.doi.org/10.1155/2013/201565

36. D. Biolek, R. Senani, V. Biolkova, and Z. Kolka, "Active elements for analog signal processing: classification, review, and new proposals," Radioengineering, vol. 17, pp. 15-32, 2008.

37. N. Herencsar, J. Koton, K. Vrba, I. Lattenberg, J. Misurec, "Generalized design method for voltagecontrolled current-mode multifunction filters," in
Proceedings of $16^{\text {th }}$ Telecommunications forum TELFOR, Serbia, 2008, pp. 400-403.

38. N. Herencsar, J. Koton, K. Vrba, I. Lattenberg, “Novel SIMO type current-mode universal filter using CFTAs and CMIs," in Proceedings of $31^{\text {st }}$ International Conference on Telecommunications and Signal Processing, Hungary, 2008, pp. 107-110.

39. N. Herencsar, J. Koton, I. Lattenberg, K. Vrba, "Signal-flow graphs for current-mode universal filter design using current follower transconductance amplifiers (CFTAs)," 2008 International Conference on Applied Electronics, Czech Republic, 2008, pp. 69-72.

40. N. Herencrar, J. Koton, K. Vrba, and V. Misurec, "A novel current-mode SIMO type universal filter using CFTAs," Contemporary Engineering Sciences, vol. 2, pp. 59-66, 2009.

41. R. Sotner, J. Petrzela, and J. Slezak, "Current mode tunable KHN filter based on controlled MOCFTAs," in Proceedings of 2009 3rd International Conference on Signals, Circuits and Systems (SCS), Tunisia, 2009, pp. 1-4. https://doi.org/10.1109/ICSCS.2009.5414170

42. N. Herencsar, J. Koton, K. Vrba, A. Lahiri, "Novel mixed-mode $\mathrm{KHN}$-equivalent filter using Z-copy CFTAs and grounded capacitors," in Proceedings of Proceedings of 4th international conference on Circuits, systems and signals, Greece, 2010, pp. 87-90.

43. N. Herencsar, J. Koton, K. Vrba, "Realization of current-mode $\mathrm{KHN}$-equivalent biquad using current follower transconductance amplifier (CFTAs)," IEICE Transactions on Fundamentals of Electronics, Communications and Computer Sciences, vol. E93-A, pp. 1816-1819, 2010. https://doi.org/10.1587/transfun.E93.A.1816

44. N. Herencsar, J. Koton, K. Vrba, I. Lattenberg, " Current follower transconductance amplifier (CFTA) -a useful building block for analog signal processing," Journal of Active and Passive Electronic Devices, vol. 6, pp. 217-229, 2011.

45. N. Herencsar, K. Vrba, J. Koton, "A novel currentmode KHN-equivalent biquad using three CFTAs," Journal of Active \& Passive Electronic Devices, vol. 7, pp. 201-208, 2012.

46. B. Singh, A. K. Singh, R. Senani, "New Universal Current-Mode Biquard Using Only Three ZCCFTAs," Radioengineering, vol. 21, pp. 273-280, 2012.

47. W. Tangsrirat, "Novel current-mode and voltagemode universal biquad filters using single CFTA," Indian Journal of Engineering \& Material Science, vol. 17, pp. 99-104, 2010.

48. N. Herencsar, J. Koton, K. Vrba, A. Lahiri, O. Cicekoglu, "Current-controlled CFTA-based currentmode SITO universal filter and quadrature oscil- 
lator," 2010 International Conference on Applied Electronics, Czech Republic, 2010, pp. 1-4

49. M. Bhusan and R. W. Newcomb, "Grounding of capacitors in integrated circuits," Electronics Letters, vol. 3, pp. 148-149, 1967.

https://doi.org/10.1049/el:19670114

50. S.-I. Liu, H.-W. Tsao, and J. Wu, "Cascadable currentmode single CCII biquads," Electronics Letters, vol. 26, pp. 2005-2006. 1990. https://doi.org/10.1049/el:19901296

51. S. Ozcan, O. Cicekoglu, and H. Kuntman, "Multiinput single-output filter with reduced number of passive elements employing single current conveyor," Computers \& Electrical Engineering, vol. 29, pp. 45-53, 2003. https://doi.org/10.1016/S0045-7906(01)00024-6

52. R. K. Sharma and R. Senani, "On the realization of universal current mode biquads using a single CFOA," Analog Integrated Circuits and Signal Processing, vol. 41, pp. 65-78, 2004. https://doi.org/10.1023/B:ALOG.0000038284.01347.2c

53. N. A. Shah, M. Quadri, and S. Z. Iqbal, "Currentmode multifunction filter using current differencing transconductance amplifier," Indian Journal of Pure \& Applied Physics, vol. 45, pp. 767-769, 2007.

54. D. Prasad, D. R. Bhaskar, and A. K. Singh, "Universal current-mode biquad filter using dual output current differencing transconductance amplifier," International Journal of Electronics and Communications, vol. 63, pp. 497-501, 2009.

https://doi.org/10.1016/j.aeue.2008.02.012

55. M. Siripruchyanun, W. Jaikla, "Current controlled current conveyor transconductance amplifier (CCCCTA): a building block for analog signal processing," Electrical Engineering, vol. 90, Issue 6, pp 443-453, 2008.

https://doi.org/10.1007/s00202-007-0095-x

56. A. Fabre, O. Saaid, F. Wiest, C. Boucheron, "High frequency applications based on a new current controlled conveyor," IEEE Transactions on Circuits and Systems I: Fundamental Theory and Applications, vol. 43, pp. 82-91, 1996.

https://doi.org/10.1109/81.486430

57. M. Kumngern, "Electronically tunable currentmode universal biquadratic filter using a single CCCFTA," in Proceedings of 2012 IEEE International Symposium on Circuits and Systems (ISCAS), Korea, 2012, pp. 1175-1178. https://doi.org/10.1109/ISCAS.2012.6271443

58. A. Fabre, "Translinear current-controlled current amplifier," Electronics Letters, vol. 24, pp. 548-549, 1988. https://doi.org/10.1049/el:19880372
59. T. Tsukutani, M. Higashimura, N. Takahashi, Y. Sumi, Y. Fukui, "Versatile voltage-mode active-only biquad with lossless and lossy integrator loop," International Journal of Electronics, vol. 88, pp. 1093-1101, 2001. https://doi.org/10.1080/00207210110071279

60. http://www.alldatasheet.com/datasheet-pdf/ pdf/66901/INTERSIL/HFA3096.html

61. W. Surakampontorn, V. Riewruja, K. Kumwachara, C. Fongsamut, "Temperature compensation of translinear current conveyor and OTA," Electronics Letters, vol. 34, pp. 707-709, 1998. https://doi.org/10.1049/el:19980525

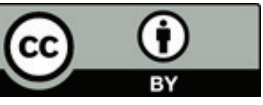

Copyright $\odot 2019$ by the Authors. This is an open access article distributed under the Creative Commons Attribution (CC BY) License (https://creativecommons.org/licenses/by/4.0/), which permits unrestricted use, distribution, and reproduction in any medium, provided the original work is properly cited.

Arrived: 21. 05. 2019

Accepted: 17. 09. 2019 